\title{
Could seafarers serve as medium of transmission of resistant bacteria?
}

\author{
Iyiola Olatunji Oladunjoye ${ }^{1} \oplus$, Yusuf Amuda Tajudeen ${ }^{1} \oplus$, Christian Tochukwu Agboeze $^{2}{ }^{\oplus}$, \\ Joy Ginika Ikebuaso ${ }^{3}\left({ }^{\circ}\right.$, Adebisi Yusuff Adebayo ${ }^{4}$ \\ ${ }^{1}$ Department of Microbiology, Faculty of Life Sciences, University of Ilorin, Ilorin, Nigeria \\ ${ }^{2}$ Department of Microbiology, Faculty of Biological Sciences, University of Nigeria, Nsukka, Nigeria \\ ${ }^{3}$ Department of Microbiology, Faculty of Natural Sciences, Chukwuemeka Odumegwu Ojukwu University, Ihiala, Nigeria \\ ${ }^{4}$ Faculty of Pharmacy, University of Ibadan, Ibadan, Nigeria
}

Antibiotic resistance remains a major threat to public health amid quest for alternative solutions to treat and curb the effects of resistant bacteria. Bacteria develop the ability to resist antibiotics by genetic mutation. This can be triggered by misuse and overuse of antibiotics in some cases. The ability to resist antibiotics can also be acquired by transfer of resistant genes between bacteria as wells as between bacteria and bacteriophages. The resistant bacteria can in turn infect humans via transmission between humans or via zoonotic transmission. This article describes the possible role of seafarers in transmission of resistant bacteria to various locations.

The significant role seafarers play in ensuring safe and efficient transportation of cargos and vessel implies that they have to move from one location to another [1]. Seafaring labour is needed because of the demand for shipping services, which in turn is derived from the demand for the products being shipped [1]. Seafarers usually consume seafood, interact with sea water and occasionally come in contact with their colleagues that are aboard. More so, they interact with people in the aquaculture business space. From a survey, both seafarers and aboard personnel eat uncooked or raw food that is not sufficiently washed and are therefore prone to the risk of communicable diseases [2].

Researches have shown that significant amount of resistant bacteria is found in seas and oceans [3]. One of the contributing factors to this is the massive use of antibiotics in treating sea animals by those involved in aquaculture business $[4,5]$. Moreover, this has become alarming because this triggers antibiotic resistance mutation in the pathogenic bacteria which can be evenly transmitted to water bodies. Consequently, the resistant bacteria in the water bodies can transfer the resistant genes acquired to other bacteria that can subsequently proceed to infect sea animals and seafarers.

Furthermore, seafarers as mediators of transmitting resistant bacteria can acquire them via the following ways: consuming raw or improperly cooked seafood housing resistant bacteria, direct contact with sea animals harbouring resistant bacteria, drinking water contaminated by resistant bacteria found in water bodies, contact with seafood handlers especially those in the aquaculture business, contact with aboard personnel. Seafarers harbouring the resistant bacteria then proceed to mediate their global transmission, starting from seaports and beyond, therefore resulting in difficult-to-treat or resistant infections.

Seafarers as a medium of transmission of resistance microbes poses a public health challenge with tackling antimicrobial resistance. There is evidence that the outcome of globalisation, human migration and urban trade contribute significantly to the spread of drug-resistant pathogens between countries [6, 7]. This calls for urgent epidemiological surveillance of resistant microbes between countries, increasing awareness of antimicrobial resistance among seafarers and promotion of antimicrobial stewardship across sections in order to curtail the possible effect of transmission of resistant microbes through seafarers.

Conflict of interest: None declared

\section{REFERENCES}

1. Talley WK. editor. The Blackwell companion to maritime economics. John Wiley \& Sons 2011. 
2. Grappasonni I, Paci P, Mazzucchi F, et al. Awareness of health risks at the workplace and of risks of contracting communicable diseases including those related to food hygiene, among seafarers. Int Marit Health. 2012; 63(1): 24-31, indexed in Pubmed: 22669809.

3. Sabatino R, Di Cesare A, Dzhembekova N, et al. Spatial distribution of antibiotic and heavy metal resistance genes in the Black Sea. Mar Pollut Bull. 2020; 160: 111635, doi: 10.1016/j.marpolbul.2020.111635, indexed in Pubmed: 32919124.

4. Schar D, Klein EY, Laxminarayan R, et al. Global trends in antimicrobial use in aquaculture. Sci Rep. 2020; 10(1): 21878, doi: 10.1038/s41598-020-78849-3, indexed in Pubmed: 33318576.

5. Preena $P$, Swaminathan $T$, Kumar V, et al. Antimicrobial resistance in aquaculture: a crisis for concern. Biologia. 2020; 75(9): 1497-1517, doi: 10.2478/s11756-020-00456-4.

6. Schwartz KL, Morris SK. Travel and the spread of drug-resistant bacteria. Curr Infect Dis Rep. 2018; 20(9): 29, doi: 10.1007/ s11908-018-0634-9, indexed in Pubmed: 29959541.

7. MemishZA, Venkatesh S, Shibl AM. Impact of travel on international spread of antimicrobial resistance. Int J Antimicrob Agents. 2003; 21(2): 135-142, doi: 10.1016/s0924-8579(02)00363-1, indexed in Pubmed: 12615377. 